\section{Dr. Reynolds, et al reply}

\section{To the Editor:}

We thank Dr. Wener for his insightful comments regarding the types of crystals causing tophaceous pseudogout. Unfortunately, more specific testing to identify the molecular nature of the crystals was not available for our patient, and the diagnosis is based on histopathology and the birefringence properties of the crystals ${ }^{1}$. However, data regarding more specific assays of the molecular structure of the crystals were available in 12 of the previous published cases.

Pritzker, et $a l^{2}$, de Vos, et $a l^{3}$, Kamatani, et $a l^{4}$, Dijkgraaf, et $a l^{5}$, and Olin, $e t a l^{6}$ identified the crystals by $\mathrm{x}$-ray powder diffraction. Aoyama, et $a l^{7}$ did not specify their technique but did quantitative analysis and found the calcium:phosphorous ratio to be 1.1:1, consistent with the calcium pyrophosphate dihydrate (CPPD) crystals. Mogi, et $a l^{8}$ Pynn, et $a l^{9}$, Vargas, et $a l^{10}$, and Strobl, et $a l^{11}$ found CPPD crystals by infrared spectrophotometry. Onodera, et $a l^{12}$ used electron-probe microanalysis and found CPPD crystals. Interestingly, Zemplenyi and Calcaterra ${ }^{13}$ found both CPPD and hydroxyapatite crystals in their patients' tissue by electronprobe elemental analysis.

Given Dr. Wener's case ${ }^{14}$, and the data from Zemplenyi and Calcaterra ${ }^{13}$, it appears that hydroxyapatite, or both CPPD and hydroxyapatite crystals, may also cause tophaceous pseudogout symptoms. It is important to screen patients with tophaceous pseudogout for parathyroid disease, as it could predispose to either CPPD or hydroxyapatite crystal deposition.

JENNIFER L. REYNOLDS, MD, Division of Rheumatology; IAN R. MATTHEW, PhD, MDentSc, BDS, FDSRCS(Eng \& Ed), Division of Oral and Maxillofacial Surgery; ANDREW CHALMERS, MD, FRCPC(Rheum), Division of Rheumatology, University of British Columbia, Vancouver, BC, Canada. E-mail: achalmers@ arthritisresearch.ca

\section{REFERENCES}

1. Reynolds JL, Matthew IR, Chalmers A. Tophaceous calcium pyrophosphate dihydrate deposition disease of the temporomandibular joint. J Rheumatol 2008;35:717-21.

2. Pritzker KPH, Phillips H, Luk SC, Koven IH, Kiss A, Houpt JB. Pseudotumor of temporomandibular joint: destructive calcium pyrophosphate dihydrate arthropathy. J Rheumatol 1976;3:70-81.

3. de Vos RAI, Brants J, Kusen GJ, Becker AE. Calcium pyrophosphate dihydrate arthropathy of the temporomandibular joint. Oral Surg Oral Med Oral Pathol 1981;51:497-502.
4. Kamatani Y, Tagawa T, Hirano Y, Nomura J, Murata M. Destructive calcium pyrophosphate dihydrate temporo-mandibular arthropathy (pseudogout). Int J Oral Maxillofac Surg 1987;16:749-52.

5. Dijkgraaf LC, de Bont LGM, Liem RSB. Calcium pyrophosphate dihydrate crystal deposition disease of the temporomandibular joint: Report of a case. J Oral Maxillofac Surg 1992;50:1003-9.

6. Olin HBD, Pedersen K, Franceis D, Hansen H, Poulsen FW. A very rare benign tumour in the parotid region: calcium pyrophosphate dihydrate crystal deposition disease. J Laryngol Otol 2001;115:504-6.

7. Aoyama S, Kino K, Amagasa T, Kayano T, Ichinose S, Kimijima Y. Differential diagnosis of calcium pyrophosphate dihydrate deposition of the temporomandibular joint. Br J Oral Maxillofac Surg 2000;38:550-3.

8. Mogi G, Kuga M, Kawauchi H. Chondrocalcinosis of the temporomandibular joint. Arch Otolaryngol Head Neck Surg 1987;113:1117-9.

9. Pynn BR, Weinberg S, Irish J. Calcium pyrophosphate dihydrate deposition disease of the temporomandibular joint. Oral Surg Oral Med Oral Pathol Oral Radiol Endod 1995;79:278-84.

10. Vargas A, Teruel J, Trull J, Lopez E, Pont J, Velayos A. Calcium pyrophosphate dihydrate crystal deposition disease presenting as a pseudotumor of the temporomandibular joint. Eur Radiol 1997;7:1452-3.

11. Strobl H, Emshoff R, Kreczy A. Calcium pyrophosphate deposition disease of the temporomandibular joint. Oral Surg Oral Med Oral Pathol 1998;85:349-51.

12. Onodera K, Ichinohasama R, Saito M, Ooya K. A case of the calcium pyrophosphate dihydrate (CPPD) deposition disease without condylar destruction of the temporomandibular joint. Pathol Int 1997;47:622-6.

13. Zemplenyi J, Calcaterra TC. Chondrocalcinosis of the temporomandibular joint. Arch Otolaryngol 1985;111:403-5.

14. Grant GA, Wener MH, Yaziji H, et al. Destructive tophaceous calcium hydroxyapatite tumor of the infratemporal fossa. Case report and review of the literature. J Neurosurg 1999;90:148-52.

J Rheumatol 2009;36:2; doi:10.3899/jrheum.080694 